\title{
Regulation of Long-Term Potentiation by H-Ras through NMDA Receptor Phosphorylation
}

\author{
Toshiya Manabe, $, 3,4$ Atsu Aiba, ${ }^{1}$ Atsushi Yamada, ${ }^{1}$ Taeko Ichise, ${ }^{1}$ Hiroyuki Sakagami, ${ }^{5}$ Hisatake Kondo, ${ }^{5}$ and \\ Motoya Katsuki ${ }^{1,2}$ \\ ${ }^{1}$ Division of DNA Biology and Embryo Engineering, Center for Experimental Medicine and ${ }^{2}$ Core Research for Evolutional \\ Science and Technology (CREST), The Institute of Medical Science, University of Tokyo, Tokyo 108-8639, Japan, \\ ${ }^{3}$ Department of Neurophysiology, Faculty of Medicine, University of Tokyo, Tokyo 113-0033, Japan, ${ }^{4}$ Department of \\ Physiology, Kobe University School of Medicine, Kobe 650-0017, Japan, and 5Division of Histology, Department of Cell \\ Biology, Graduate School of Medical Sciences, Tohoku University, Sendai 980-8575, Japan
}

The proto-oncogene ras plays a critical role in cell proliferation and differentiation. However, ras genes are abundantly expressed in the adult CNS, although neuronal cells normally do not proliferate. Recently, several lines of evidence implicated the involvement of Ras signaling pathway in synaptic plasticity. To explore the role of the Ras proteins in the CNS, we generated knock-out mice lacking the $\mathrm{H}$-ras gene and then used them to study the roles of Ras in synaptic transmission and plasticity. An investigation of protein phosphorylation and synaptic transmission in $\mathrm{H}$-ras null mutant mice has shown that the NMDA receptor is a final target molecule of the Ras protein pathway in the CNS. In the H-ras null mutant hippocampus, the tyrosine

It is well established that proto-oncogene ras plays a critical role in cell proliferation and differentiation, as well as in oncogenesis (Lowy and Willumsen, 1993). In mammals, three distinct ras genes (H-ras, N-ras, and K-ras) have been identified (Ellis et al., 1981; Shimizu et al., 1983; Ruta et al., 1986), each encoding homologous but distinct $21 \mathrm{kDa}$ proteins. The Ras proteins function as molecular switches that are activated by binding GTP catalyzed by Ras guanine nucleotide exchange factors (GEFs) and inactivated by the conversion of bound GTP to GDP by an intrinsic GTPase activity and GTPase activating proteins (GAPs) (Lowy and Willumsen, 1993). ras genes are abundantly expressed in the adult mouse CNS (Leon et al., 1987), and several lines of evidence implicated the involvement of Ras signaling pathway in synaptic plasticity and learning. The mice lacking neuronspecific GEF, Ras-guanine-nucleotide-releasing factor (GRF), showed impairment of LTP in the amygdala despite normal

\footnotetext{
Received Nov. 19, 1999; revised Jan. 7, 2000; accepted Jan. 25, 2000.
}

This work was supported in part by Grants-in-Aid for Scientific Research on Priority Areas, for Cancer Research and for Scientific Research from the Ministry of Education, Science, Sports, and Culture, Japan, Grants-in-Aid from the Ministry of Health and Welfare, Japan, the Uehara Memorial Foundation, and the Mitsubishi Foundation. We are grateful to R. Nicoll, S. Tonegawa, T. Takahashi, D. Saffen, M. Kano, N. Suzuki, and K. Kobayashi for their comments on this manuscript, H. Umemori and T. Yamamoto for the assay of tyrosine phosphorylation of NMDA receptors and an anti-NR2B antibody, S. Nakanishi for an anti-NR2A antibody, and K. Nakamura, K. Nakao, and K. Ise for generation of the H-ras mutant mice. We also thank K. Katsuki and Y. Ikeda for their excellent technical assistance and K. Tsurui, T. Kohyama, and M. Tanaka for their help in maintaining the animals.

Drs. Manabe and Aiba contributed equally to this work.

Correspondence should be addressed to Dr. Motoya Katsuki, Division of DNA Biology and Embryo Engineering, Center for Experimental Medicine, The Institute of Medical Science, University of Tokyo, 4-6-1 Shirokanedai, Minato-ku, Tokyo 108-8639, Japan. E-mail: katsuki@ims.u-tokyo.ac.jp.

Copyright (c) 2000 Society for Neuroscience $0270-6474 / 00 / 202504-08 \$ 15.00 / 0$ phosphorylation of NR2A $(\epsilon 1)$ and NR2B $(\epsilon 2)$ subunits of NMDA receptors is increased, and, correspondingly, NMDA synaptic responses are selectively enhanced. In addition, long-term potentiation is markedly enhanced in mutant mice, most likely because of a selective enhancement of NMDA synaptic responses. Therefore, although Ras proteins have been implicated in cell proliferation and differentiation, the regulation of activity-dependent synaptic plasticity in the adult animals by downregulation of the phosphorylation of the NMDA receptor may be another major and pivotal role for $\mathrm{H}$-Ras protein.

Key words: long-term potentiation; NMDA receptor; $H$-Ras; tyrosine phosphorylation; hippocampus; mutant mice hippocampal long-term potentiation (LTP) (Brambilla et al., 1997). In addition, an inhibitor of extracellular response kinase cascades, which are activated by activated Ras, inhibits hippocampal LTP induction (English and Sweatt, 1997). Furthermore, a novel RasGAP, termed p135 SynGAP, that associates with the postsynaptic density (PSD)-95 protein family has been found recently (Chen et al., 1998; Kim et al., 1998). These results prompted us to search for the novel functions of the Ras proteins in neural plasticity.

The NMDA receptor plays a central role in development, plasticity, and neurotoxicity in the CNS. LTP of excitatory synaptic transmission in the hippocampus is a candidate for the cellular mechanism underlying neural plasticity, such as learning and memory (Bliss and Collingridge, 1993). The activation of NMDA receptors (Collingridge et al., 1983) and the influx of $\mathrm{Ca}^{2+}$ to the postsynaptic cell through the receptor (Lynch et al., 1983; Malenka et al., 1988) are essential for the induction of LTP in the CA1 region of the hippocampus. The NMDA receptor is

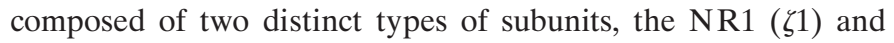
NR2A-NR2D ( $\epsilon 1-\epsilon 4)$ (Kutsuwada et al., 1992; Monyer et al., 1992; Ishii et al., 1993). The NMDA receptor channel activities are regulated by either a receptor subunit composition or posttranslational modifications. The NMDA receptors are known to be phosphorylated and modulated by serine/threonine kinases, such as protein kinase C (Chen and Huang, 1992) and protein tyrosine kinases (PTKs) (Wang and Salter, 1994), such as Src family kinases (Yu et al., 1997).

Here, we report that, in the H-ras deficient mice, tyrosine phosphorylation of NMDA receptors is increased without a change in the subunit composition of NMDA receptors. The 
magnitude of mutant LTP is almost double that of wild-type mice. This effect is most likely attributable to a selective enhancement of the NMDA synaptic responses induced by an increase in the tyrosine phosphorylation of NMDA receptors. Therefore, the protein encoded by the $\mathrm{H}-\mathrm{ras}$ gene is a key molecule that regulates LTP induction by the downregulation of the NMDA receptor activity.

\section{MATERIALS AND METHODS}

Mice. When comparing wild-type and H-ras(-/-) mice, littermates from heterozygous parents were used in most cases, although in some cases, age-matched animals were also used. All experiments using mice were performed in accordance with the animal use guidelines at each institute.

In situ hybridization. The nucleotide sequence of the probe was complementary to the H-ras cDNA (5'GCCAGGACCACTCTCATCGGGTGGGTTCAGTTTCCGCAATTTATG3'). Brains of adult wild-type and mutant mice were quickly removed under ether anesthesia and frozen in powdered dry ice. The sagittal sections were cut on a cryostat at a thickness of $25 \mu \mathrm{m}$ and mounted onto silane-coated glass slides. The sections were immersed in $4 \%$ paraformaldehyde for 10 min and acetylated in $0.25 \%$ acetic anhydrate $-0.1 \mathrm{~m}$ triethanolamine, $\mathrm{pH} 8.0$, for 10 min at room temperature. After prehybridization, the sections were incubated overnight at $42^{\circ} \mathrm{C}$ in the solution containing $50 \%$ deionized formamide, $4 \times$ SSC $(1 \times$ SSC: $0.15 \mathrm{M} \mathrm{NaCl}$ and $0.015 \mathrm{M}$ sodium citrate, $\mathrm{pH} 7.4), 1 \times$ Denhardt's solution $(0.02 \%$ each of polyvinylpyrolidone, bovine serum albumin, and Ficoll), $1 \%$ sodium $N$-lauroyl sarcosinate (Sarkosyl), $0.1 \mathrm{~m}$ phosphate buffer, $\mathrm{pH} 7.2,250 \mu \mathrm{g} / \mathrm{ml}$ heat-denatured salmon sperm DNA, $10 \%$ dextran sulfate, $100 \mathrm{~mm}$ dithiothreitol, and ${ }^{35}$ S-labeled oligonucleotide probe $\left(5-10 \times 10^{5} \mathrm{cpm} / 50 \mu \mathrm{l}\right)$. The sections were then washed in $0.1 \times$ SSC $-0.1 \%$ Sarkosyl at $50^{\circ} \mathrm{C}$ four times for 30 min. The sections were exposed to Hyperfilm $\beta$-max (Amersham Pharmacia Biotech, Uppsala, Sweden) for 2 weeks at room temperature.

Western blot. The hippocampus was homogenized in radioimmunoprecipitation assay (RIPA) buffer (20 mm Tris- $\mathrm{HCl}, 150 \mathrm{~mm} \mathrm{NaCl}, 0.1 \%$ SDS, $1 \%$ sodium deoxycholate, $1 \%$ Triton $\mathrm{X}-100,2$ mm EDTA, $50 \mathrm{~mm}$ $\mathrm{NaF}, 1 \mathrm{~mm}$ sodium orthovanadate, $20 \mu \mathrm{g} / \mathrm{ml}$ aprotinin, and $20 \mu \mathrm{g} / \mathrm{ml}$ leupeptin). Cellular fractions containing synaptosomes and PSDs were prepared as described by Carlin et al. (1980). Proteins were separated by electrophoresis on SDS-PAGE. The proteins were then transferred to the polyvinylidene difluoride (PVDF) membranes (Bio-Rad, Hercules, $\mathrm{CA}$ ), and immunoblots were probed with monoclonal anti-pan Ras (Calbiochem, San Diego, CA), polyclonal anti-H-Ras (Santa Cruz Biotechnology, Santa Cruz, CA), monoclonal anti-N-Ras (Santa Cruz Biotechnology), and monoclonal anti-K-Ras (Santa Cruz Biotechnology) antibodies and were visualized by enhanced chemiluminescence (ECL; Amersham Pharmacia Biotech).

Immunoprecipitation and detection of tyrosine phosphorylation. Hippocampus lysates were homogenized in RIPA buffer containing $0.5 \%$ SDS. After boiling the lysates, they were diluted by RIPA buffer lacking SDS to $0.1 \%$ SDS (Sheng et al., 1994) and centrifuged for $20 \mathrm{~min}$ at $18,000 \times g$. The supernatants were incubated at $4^{\circ} \mathrm{C}$ with protein G-Sepharose (Amersham Pharmacia Biotech) overnight. After centrifugation, $200 \mu \mathrm{g}$ of precleared lysates were incubated with a monoclonal anti-NR2A antibody (a gift from Dr. S. Nakanishi, Kyoto University Faculty of Medicine, Kyoto, Japan) or affinity-purified polyclonal antiNR2B antibodies (a gift from Drs. T. Yamamoto and H. Umemori, Institute of Medical Science, University of Tokyo, Tokyo, Japan) raised to synthetic peptide HGAVPGRFQKDI corresponding to amino acids $1407-1418$ of NR2B at $4^{\circ} \mathrm{C}$ for $1 \mathrm{hr}$. Immune complexes were isolated by the addition of protein G-Sepharose followed by incubation for $1 \mathrm{hr}$ at $4^{\circ} \mathrm{C}$. The resulting immune complexes were washed five times with RIPA buffer, resuspended in Laemli sample buffer, and boiled for $5 \mathrm{~min}$. Proteins were separated by SDS-PAGE. The proteins were then transferred to PVDF membranes, and immunoblots were probed with an anti-phosphotyrosine antibody (anti-PY) linked to horse radish peroxidase (RC20:HRPO; Transduction Laboratories, Lexington, KY). The amount of anti-PY bound to the $180 \mathrm{kDa}$ band was quantified by densitometry of the $\mathrm{x}$-ray films. The ratio of the amount of anti-PY bound in wild-type and mutant mice to the mean of that in wild-type mice on the same blot was calculated, and then the normalized values on different blots were averaged.

To examine the subunit composition and tyrosine phosphorylation of the heteromeric complexes of native NMDA receptors, hippocampal lysates solubilized in RIPA buffer were immunoprecipitated with polyclonal anti-NR1 antibodies (Upstate Biotechnology, Lake Placid, NY), and immunoblots were probed with polyclonal anti-NR1 (Chemicon, Temecula, CA), polyclonal anti-NR2A (Santa Cruz Biotechnology), polyclonal anti-NR2B (Santa Cruz Biotechnology), anti-PY, and polyclonal anti-PSD-95 (Santa Cruz Biotechnology) antibodies.

The PTK activity was assayed using Universal Tyrosine Kinase Assay Kit (Takara Shuzo, Otsu, Shiga, Japan). The procedure was a modification of that described by Rijksen et al. (1991). Protein lysates were incubated with a substrate poly(Glu-Tyr) immorbilized to microplates and unlabeled ATP in the presence of $1 \mathrm{~mm}$ sodium-orthovanadate and $50 \mathrm{~mm} \mathrm{NaF}$. After termination of the reaction, the extent of tyrosine phosphorylation was measured by ELISA with anti-phosphotyrosine (PY20:HRPO) and HRPO substrate, 3,3',5,5'-tetramethylbenzidine. One unit $(\mathrm{U})$ is defined as the activity of c-Src protein, which can transfer 1 pmol of $\gamma$-phosphate of ATP to the substrate per minute.

The data are expressed as the means \pm SEMs. Student's $t$ test was used to determine whether there was a significant difference $(p<0.05)$ in the mean between the two sets of data.

Electrophysiology. Hippocampal slices (400- $\mu$ m-thick) were prepared from 6- to 12-week old mice and placed in a holding chamber for at least $1 \mathrm{hr}$. A single slice was then transferred to the recording chamber and submerged beneath a continuously perfusing medium that had been saturated with $95 \% \mathrm{O}_{2}$ and $5 \% \mathrm{CO}_{2}$. The composition of the medium was (in mM): $119 \mathrm{NaCl}, 2.5 \mathrm{KCl}, 1.3 \mathrm{MgSO}_{4}, 2.5 \mathrm{CaCl}_{2}, 1.0 \mathrm{NaH}_{2} \mathrm{PO}_{4}, 26.2$ $\mathrm{NaHCO}_{3}$, and 11 glucose. All the perfusing solutions contained $100 \mu \mathrm{M}$ picrotoxin to block $\mathrm{GABA}_{\mathrm{A}}$ receptor-mediated inhibitory synaptic responses. The field potential recordings were made with a glass electrode $(3 \mathrm{M} \mathrm{NaCl})$ placed in the stratum radiatum. The whole-cell pipette solution contained (in $\mathrm{mm}$ ): 122.5 cesium gluconate, $17.5 \mathrm{CsCl}, 10$ HEPES, 0.2 EGTA, $8 \mathrm{NaCl}, 2 \mathrm{Mg}$-ATP, and $0.3 \mathrm{Na}_{3}$-GTP, pH 7.2 (osmolarity 290-300 mOsm). In the whole-cell recordings, the values of the membrane potential were corrected for the liquid junction potential at the electrode tip. An Axopatch 1D amplifier (Axon Instruments, Foster City, CA) was used, and the signal was filtered at $1 \mathrm{kHz}$, digitized at $5-10 \mathrm{kHz}$, and stored on an IBM-compatible computer equipped with a Labmaster analog-to-digital board (Axon Instruments). For evoking synaptic responses, a bipolar tungsten stimulating electrode was placed in the stratum radiatum, and Schaffer collateral-commissural fibers were stimulated at $0.1 \mathrm{~Hz}$. For LTP experiments, the stimulus strength was adjusted so that it gave rise to AMPA receptor-mediated EPSPs of the slope value between 0.10 and $0.15 \mathrm{mV} / \mathrm{msec}$. For the analysis of EPSPs, we measured their early rising phase to avoid contamination of voltagedependent components as much as possible. All experiments were done at room temperature. The data are expressed as the means \pm SEMs. Student's $t$ test was used to determine whether there was a significant difference $(p<0.05)$ in the mean between the two sets of data. The majority of electrophysiological experiments were performed in a blind manner, and the results were essentially identical to those of the nonblind experiments, and thus all the data were pooled.

\section{RESULTS \\ Expression of $\mathbf{H}-r a s$ gene}

The distribution of H-ras mRNAs in the brain examined by in situ hybridization showed that the H-ras gene is abundantly expressed in the CNS, including the hippocampus, cerebral cortex, cerebellum, and striatum, of normal mice (Fig. 1a). A Western blot analysis of the amount of the H-Ras protein in whole-cell extracts from the cerebral cortex or in the fraction containing synaptosomes and mitochondria, the synaptosome fraction, and the PSD fraction (Carlin et al., 1980) showed that H-Ras protein exists in the synaptosome but not in the PSD fraction (Fig. 1e). Because we confirmed the existence of $\mathrm{H}$-Ras protein in neurons, mice lacking the H-ras gene $[\mathrm{H}-\operatorname{ras}(-/-)]$ were generated to examine the roles of Ras proteins in the CNS. H-ras $(-/-)$ mice appeared to be healthy and bred and developed normally. Their life spans were the same as those of the wild-type littermates, and their behavior also appeared to be normal. A histological examination of various brain regions, including the striatum, hippocampus (Fig. 1d), cerebral cortex, and cerebellum in the mutant mice showed no obvious morphological abnormalities at the micro- 


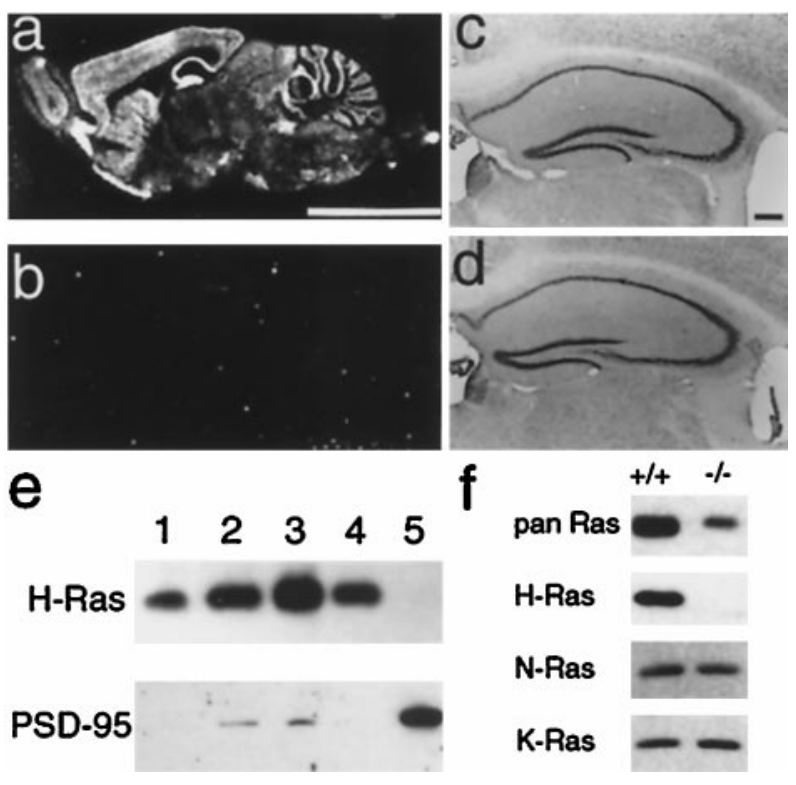

Figure 1. Expression of H-ras gene in the CNS. $a, b$, In situ hybridization analyses of H-ras mRNA in the CNS of wild-type $(a)$ and $\mathrm{H}$-ras $(-/-)$ mice $(b)$. Scale bar, $5 \mathrm{~mm}$. $c, d$, A Nissl staining of the hippocampus sections of wild-type $(c)$ and H-ras $(-/-)$ mice $(d)$. Scale bar, $250 \mu \mathrm{m} . e$, A Western blot analysis of H-Ras and PSD-95 proteins in the fraction from the mouse cerebral cortex. Whole-cell extract (lane 1, $10 \mu \mathrm{g}$ ) and the fractions containing synaptosome and mitochondria (lane 2, $10 \mu \mathrm{g}$ ), synaptosome (lane 3, $10 \mu \mathrm{g}$; lane 4, $5 \mu \mathrm{g}$ ), and isolated PSD (lane 5, $5 \mu \mathrm{g}$ ) were separated by SDS-PAGE and subjected to immunoblotting. $f, \mathrm{~A}$ Western blot analysis of the Ras proteins with anti-pan Ras, anti-H-Ras, anti-N-Ras, and anti-K-Ras antibodies in the wild-type $(+/+)$ and H-ras (-/-) hippocampus.

scopic level. In situ hybridization analyses of brain slices with oligonucleotide probes indicated that H-ras mRNAs are absent in H-ras $(-/-)$ mice (Fig. 1b). We examined the amount of Ras proteins in the H-ras $(-/-)$ hippocampus lysate. Immunoreactivity with an anti-pan Ras antibody that recognizes all three types of Ras protein was drastically decreased in the mutant lysate (Fig. 1f) compared with that in the wild-type lysate, suggesting that most of Ras proteins are the H-Ras proteins in the mouse hippocampus. The amount of N-Ras or K-Ras proteins was not significantly different between wild-type and $\mathrm{H}$-ras-deficient mice, whereas the $\mathrm{H}$-Ras proteins were absent in $\mathrm{H}-\operatorname{ras}(-/-)$ mice (Fig. $1 f)$.

\section{Increase in tyrosine phosphorylation of NMDA receptors without an alteration of the subunit composition in $\mathrm{H}-$ ras(-/-) mice}

We next examined the tyrosine phosphorylation and the subunit composition of NMDA receptors in H-ras $(-/-)$ mice. We first examined the tyrosine phosphorylation of NR2A and NR2B after a dissociation of the NMDA receptor complexes (Sheng et al., 1994). The proteins $(200 \mu \mathrm{g})$ from the wild-type and H-ras $(-/-)$ lysates were boiled in $0.5 \%$ SDS followed by dilution into RIPA buffer and then were immunoprecipitated with antiNR2A or anti-NR2B antibodies. The resulting immune complexes were blotted with anti-PY (Fig. 2a). The amounts of anti-PY bound to both NR2A (155 $\pm 14 \%$ of wild type; $n=16)$ and NR2B $(172 \pm 23 \%$ of wild type; $n=16)$ in the H-ras $(-/-)$ were significantly larger $(p<0.01)$ than those in the wild type $(\mathrm{NR} 2 \mathrm{~A}, 100 \pm 11 \%, n=16$; NR2B, $100 \pm 5 \%, n=16)$. Next, the hippocampus proteins solubilized in RIPA buffer were coimmu- noprecipitated by an anti-NR1 antibody to examine the subunit composition and tyrosine phosphorylation of the heteromeric complexes of native NMDA receptors in wild-type and mutant mice. The amount of NR1, NR2A, and NR2B coprecipitated with the anti-NR1 antibody was not altered in the H-ras $(-/-)$ lysates (Fig. $2 b$ ). The same blot probed with anti-PY showed a single $180 \mathrm{kDa}$ band (Fig. 2b, bottom right). Because no $180 \mathrm{kDa}$ tyrosine-phosphorylated protein other than NR2A or NR2B is known in the NMDA receptor complex, the tyrosine phosphorylation of the $180 \mathrm{kDa}$ protein coprecipitated with the anti-NR1 antibody is likely to correspond to that of NR2A and NR2B. Anti-PY bound to the $180 \mathrm{kDa}$ protein was significantly larger $(p<0.05)$ in the H-ras $(-/-)$ lysates $(137 \pm 3 \%$ of wild type; $n=3)$ than that in the wild type $(100 \pm 18 \% ; n=3)$ (Fig. $2 b)$, suggesting that the phosphorylation of NR2A and NR2B was increased in the NMDA receptor complex in the H-ras $(-/-)$ mice. Furthermore, we examined the amount of PSD-95 proteins that may be required for the localization of NMDA receptors to synapses and found that the amount of PSD-95 proteins in the NMDA receptor complex is not significantly changed in H-ras (-/-) mice (Fig. 2c).

Because we found the increase of tyrosine phosphorylation of NR2A and NR2B in the H-ras (-/-) hippocampus, we measured PTK activity with the synthetic peptide poly(Glu-Tyr) as a general PTK substrate in the hippocampal lysates in the presence of tyrosine phosphatase inhibitors (Rijksen et al., 1991). The $\mathrm{H}-\mathrm{ras}(-/-)$ lysates had a significant $18 \%$ increase in the activity of PTKs when compared with wild-type lysates (wild type, $3.03 \pm$ $0.09 \times 10^{-2} \mathrm{U} / \mu \mathrm{g}, n=8 ; \mathrm{H}-r a s(-/-), 3.56 \pm 0.13 \times 10^{-2} \mathrm{U} / \mu \mathrm{g}$, $n=8 ; p<0.01)$. These results suggest that $\mathrm{H}$-Ras proteins regulate NMDA receptors by downregulation of tyrosine phosphorylation without changing the subunit composition and interaction between NMDA receptors and PSD-95 proteins in normal animals.

\section{Upregulation of NMDA receptor-mediated synaptic responses in $\mathrm{H}$-ras-deficient mice}

We next investigated excitatory synaptic transmission in hippocampal slices of H-ras (-/-) and wild-type mice to study the effects of these biochemical changes on the synaptic functions in the CNS. EPSCs were evoked in CA1 pyramidal cells using whole-cell patch-clamp techniques by stimulating Schaffer collateral-commissural fibers in the stratum radiatum. We first examined whether NMDA receptor-mediated EPSCs are modified by the increase in phosphorylation of NMDA receptor subunits in H-ras (-/-) mice (Fig. 3a,b). AMPA receptor-mediated EPSCs were recorded at a membrane potential of $-90 \mathrm{mV}$ in a voltageclamp mode. NMDA EPSCs were then measured at the same stimulus strength in the presence of 6-cyano-7-nitroquinoxaline2,3-dione (CNQX) $(10 \mu \mathrm{M})$, a non-NMDA receptor antagonist, at $+40 \mathrm{mV}$ to relieve the voltage-dependent $\mathrm{Mg}^{2+}$ block of the NMDA receptor channel (Mayer et al., 1984; Nowak et al., 1984). The ratio of NMDA to AMPA EPSC amplitudes (Sakimura et al., 1995) was significantly larger $(p<0.02)$ (Fig. 3b) in H-ras $(-/-)$ mice $(59.9 \pm 5.2 \%, n=12$ cells and 6 mice $)$ than in wild-type mice (44.3 $\pm 4.9 \%, n=13$ cells and 7 mice), suggesting that the modulation of NMDA receptors may enhance the NMDA synaptic responses in $\mathrm{H}-\mathrm{ras}(-/-)$ mice. However, it is also possible that the larger NMDA/AMPA ratio is attributable to a selective reduction of AMPA synaptic responses. To differentiate these possibilities, we examined the input-output relationships of the AMPA and NMDA EPSPs in wild-type and H-ras(-/-) mice 

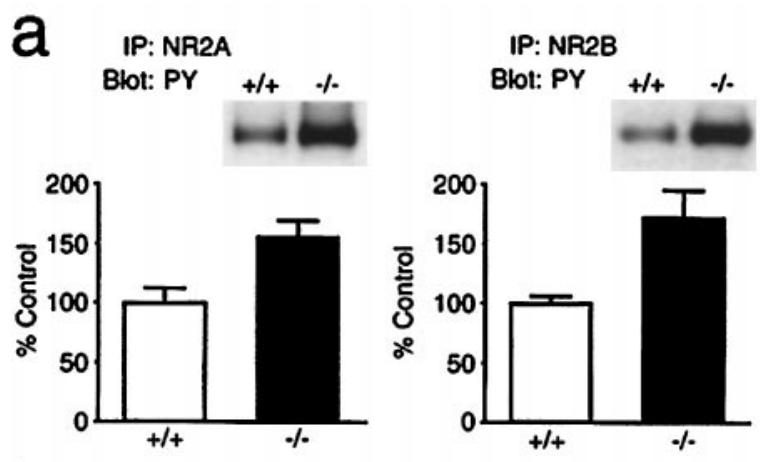

b
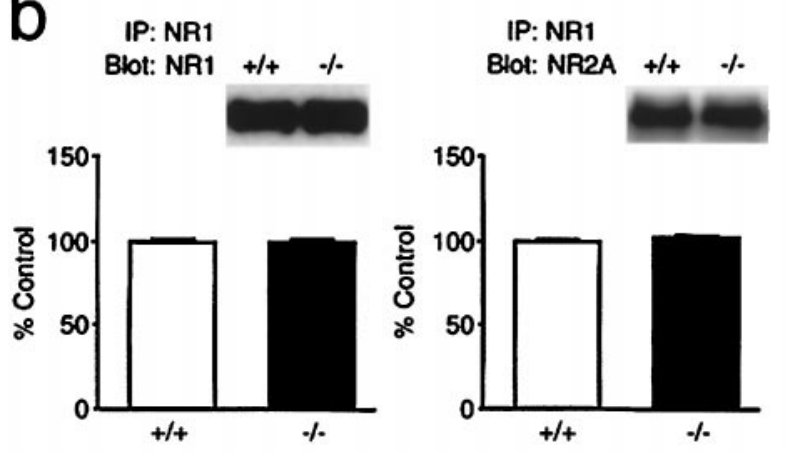

IP: NR1

Blot: NR2B +1+ $\%$

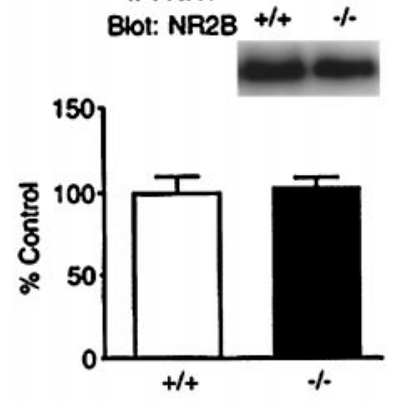

IP: NR1

Blot: PY
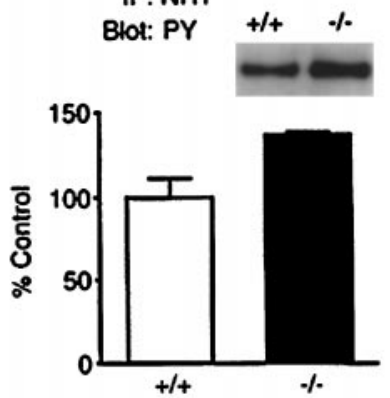

C

IP: NR1

Blot: NR1
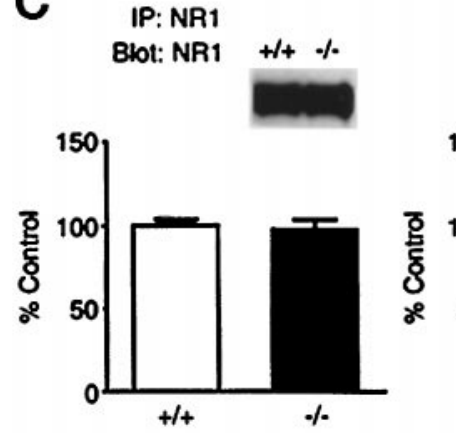

IP: NR1

Blot: PSD-95 +1+ \%

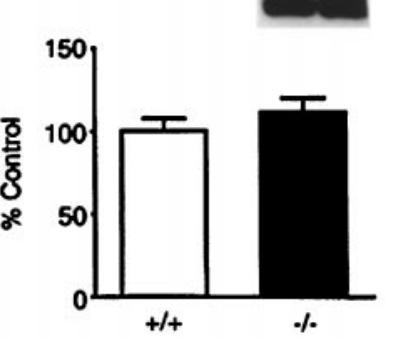

Figure 2. Tyrosine phosphorylation of NR2A and NR2B in the wild-type $(+/+)$ and H-ras $(-/-)$ hippocampus. $a$, Hippocampal proteins $(200 \mu \mathrm{g})$ solubilized in boiling SDS followed by dilution into RIPA buffer were incubated with anti-NR2A or anti-NR2B antibodies. Immunoprecipitation $(I P)$ with anti-NR2A or anti-NR2B antibodies was separated by SDS-PAGE and immunoblotted with the anti-PY. The amount of antibodies bound to each band was quantified by densitometry of the x-ray films, and values were normalized to the mean of wild-type values. The normalized amount of anti-PY bound to NR2A and NR2B in H-ras $(-/-)$ mice was significantly larger $(p<0.01)$ than that in wild-type mice. The insets are representative immunoblots with the anti-PY. $b$, Hippocampus proteins $(200 \mu \mathrm{g})$ solubilized in RIPA buffer were incubated with an anti-NR1 antibody. Immunoprecipitation with the anti-NR1 antibody was separated by SDS-PAGE and transferred to PVDF membrane. The membrane was then analyzed by sequential blotting using anti-NR1,
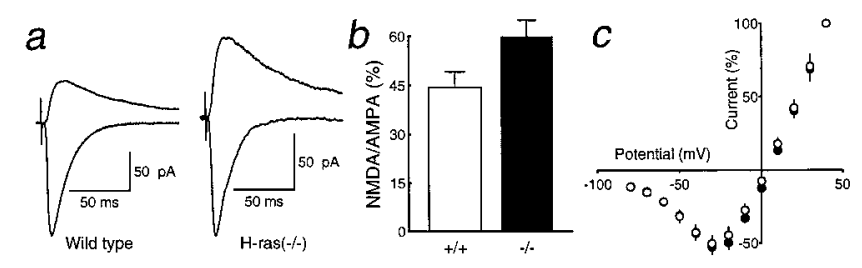

$d$

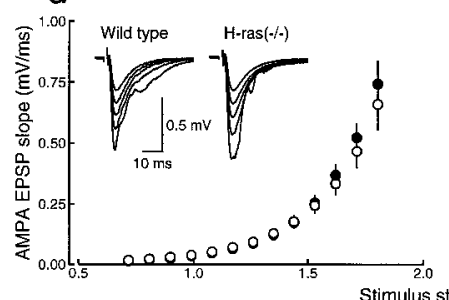

e

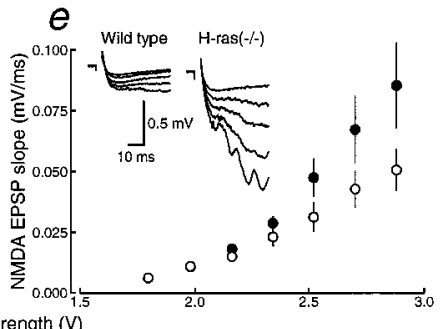

Figure 3. NMDA synaptic responses are larger in H-ras(-/-) mice. a, AMPA receptor-mediated EPSCs (downward traces) and NMDA receptor-mediated EPSCs (upward traces) were recorded at membrane potentials of -90 and $+40 \mathrm{mV}$, respectively. When NMDA EPSCs were recorded, $10 \mu \mathrm{M}$ CNQX was present to block AMPA EPSCs. $b$, The ratio of amplitudes of the NMDA EPSC to those of the AMPA EPSC was calculated for each cell, and the values were then averaged for all cells. The ratio was significantly larger in $\mathrm{H}-\operatorname{ras}(-/-)$ mice than in wild-type mice $(p<0.02)$. $c$, The current-voltage relationships of NMDA synaptic currents in wild-type (open circles; $n=9$ cells, 5 mice) and H-ras $(-/-)$ ( filled circles; $n=7$ cells, 4 mice) mice. Current amplitudes, which were larger in H-ras $(-/-)$ mice, were normalized to the value obtained at +40 $\mathrm{mV}$ for easier comparison. $d$, The input-output relationships of AMPA EPSPs of wild-type (open circles; $n=10$ slices, 5 mice) and H-ras $(-/-)$ (filled circles; $n=10$ slices, 5 mice) mice. Sample traces in the inset represent the responses evoked with five different stimulus intensities varying from 1.35 to $1.71 \mathrm{~V}$.e , The input-output relationships of NMDA EPSPs of wild-type (open circles; $n=14$ slices, 7 mice) and $\mathrm{H}-\mathrm{ras}(-/-)$ ( filled circles; $n=14$ slices, 7 mice) mice. CNQX (10 $\mu \mathrm{M})$ was present to block AMPA receptor-mediated synaptic responses. Sample traces in the inset represent the responses evoked with five different stimulus intensities varying from 2.16 to $2.88 \mathrm{~V}$. Stimulation with higher intensities was used to overcome the $\mathrm{Mg}^{2+}$ block of the NMDA receptor. As shown in the inset, in H-ras (-/-) mice, NMDA EPSPs were often accompanied by bursting activity, presumably because of their large size. In some experiments, $40 \mu \mathrm{M}$ D-APV was applied at the end of the experiments, and the synaptic responses were completely abolished.

using extracellular field potential recording techniques. The input-output relationship of the AMPA synaptic responses was similar in both groups (Fig. 3d), but NMDA synaptic responses were larger in mutant mice (Fig. 3e), indicating that the larger NMDA/AMPA ratio observed in the whole-cell recordings is attributable to an absolute increase in the NMDA synaptic responses in H-ras $(-/-)$ mice.

The enhanced NMDA synaptic responses could be introduced by changes in the biophysical properties of the receptor. However, the rise time (wild type, $13.5 \pm 0.3 \mathrm{msec}, n=13$ cells and 7 mice; H-ras $(-/-), 13.1 \pm 0.4 \mathrm{msec}, n=12$ cells and 6 mice;

anti-NR2A, anti-NR2B, and anti-PY antibodies. The amount of NR1, NR2A, and NR2B coprecipitated with the anti-NR1 antibody was not altered in the H-ras $(-/-)$ lysates. Tyrosine phosphorylation of $180 \mathrm{kDa}$ proteins coprecipitated with the anti-NR1 antibody was significantly larger $(p<0.05)$ in the H-ras $(-/-)$ lysates than that in the wild type. The insets are representative immunoblots with each antibody. $c$, The membrane blotted with the same immunoprecipitation as in $b$ was analyzed by sequential blotting using anti-NR1 and anti-PSD-95 antibodies. The amount of PSD-95 coprecipitated with the anti-NR1 antibody was not significantly changed in the H-ras $(-/-)$ lysates. 
$p>0.2$ ) and the decay time constant (wild type, $57.5 \pm 4.2$ msec; H-ras $(-/-), 55.2 \pm 4.2 \mathrm{msec} ; p>0.3)$ of the NMDA synaptic currents measured at $+40 \mathrm{mV}$ with whole-cell recordings were similar between the wild-type and H-ras $(-/-)$ mice, indicating that the kinetics of the NMDA receptors is not modified in the H-ras $(-/-)$ mice. Furthermore, the $I-V$ curves of wild-type and mutant mice were almost superimposable (Fig. 3c), which suggests that the larger NMDA synaptic responses are not caused by a modulation of the voltage-dependent $\mathrm{Mg}^{2+}$ block of the NMDA receptor. It is thus possible that the enhanced synaptic NMDA responses in H-ras $(-/-)$ mice are associated with an increase in the single channel conductance of the existing receptor channel and/or an increase in the number of active NMDA receptor channels.

\section{Enhanced LTP in H-ras-deficient mice}

It is well established that the induction of LTP at the Schaffer collateral-commissural-CA1 synapse is mediated by the activation of postsynaptic NMDA receptors (Collingridge et al., 1983; Nicoll and Malenka, 1995). EPSPs were recorded in the CA1 region using extracellular field potential recording techniques. The stimulation of afferent fibers evoked AMPA receptormediated EPSPs in the stratum radiatum. The tetanic stimulation of the afferent fibers $(100 \mathrm{~Hz}$ for $1 \mathrm{sec}$, repeated twice at a $10 \mathrm{sec}$ interval) gave rise to LTP of excitatory synaptic transmission in wild-type mice (Fig. 4a,b). The magnitude of LTP in the H-ras $(-/-)$ mice induced by the same conditioning was remarkably larger than that in the wild-type mice (Fig. $4 a, b)$. The induction of LTP in the H-ras(-/-) mice was completely blocked by the NMDA receptor antagonist D-2-amino-5-phosphonovaleric acid (D-APV) $(50 \mu \mathrm{M} ; n=2$ slices and 1 mouse), indicating that the increased magnitude of LTP was not caused by the addition of NMDA receptor-independent potentiation. In some separate experiments, to examine whether the synaptic NMDA responses during the conditioning for inducing LTP are also larger in mutant mice, depolarization caused by tetanic stimulation was measured (Fig. 4c, $d$ ). As expected, the component of depolarization that was sensitive to D-APV was significantly larger in the H-ras (-/-) mice [the ratio of NMDA receptor-dependent depolarization to AMPA receptor-dependent depolarization (see the figure legend): wild-type, $61.5 \pm 11.0 \%, n=4$ slices and 4 mice; H-ras $(-/-), 94.8 \pm 11.3 \%, n=5$ slices and 5 mice; $p<0.04]$, indicating that the NMDA receptor is more active in $\mathrm{H}-\operatorname{ras}(-/-)$ mice during tetanic stimulation.

Although the larger magnitude LTP in H-ras (-/-) mice is most likely attributable to the enhanced NMDA receptor activity, it is also possible that a change in the presynaptic transmitter release probability may be involved in the modulation of LTP. We thus examined the paired-pulse facilitation (PPF) (Zucker, 1989; Manabe et al., 1993) of AMPA receptor-mediated EPSCs to assess whether H-ras knock-out may affect the presynaptic release mechanisms. PPF induced at an interstimulus interval of $50 \mathrm{msec}$ was not significantly different $(p>0.3)$ between wild-type (1.85 $\pm 0.06, n=18$ cells and 9 mice) and H-ras $(-/-)(1.89 \pm$ $0.08, n=12$ cells and 6 mice) mice (Fig. 5a,b), suggesting that presynaptic release probability is not affected by H-Ras proteins.

The data presented above strongly suggest that the enhanced LTP in H-ras $(-/-)$ mice results from the larger synaptic NMDA responses. If the enhanced LTP is solely a result of an increased $\mathrm{Ca}^{2+}$ influx through the NMDA receptors and not a result of a modification of LTP expression mechanisms, then the LTP saturation level of the H-ras $(-/-)$ mice should be similar to that of
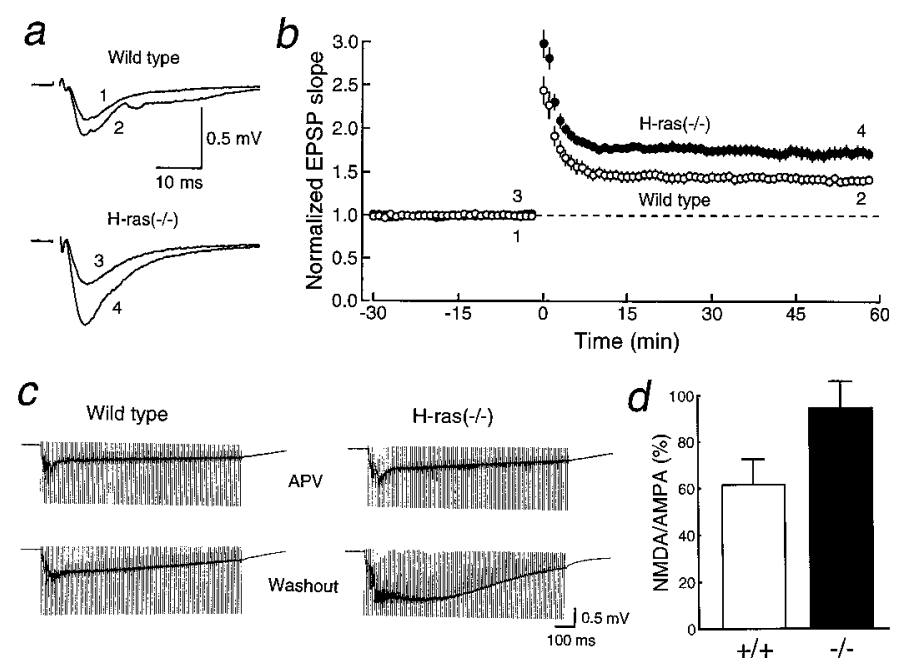

Figure 4. LTP is enhanced in H-ras $(-/-)$ mice. $a$, Sample traces of field EPSPs (average of 10 consecutive responses) of wild-type and H-ras $(-/-)$ mice recorded at the times indicated in $b$. The stimulus artifacts are truncated. $b$, The averaged time course of LTP in wild-type $(n=13$ slices, 10 mice) and H-ras $(-/-)(n=16$ slices, 12 mice $)$ mice. Initial EPSP slopes were measured, and the values were normalized in each experiment using the averaged slope value measured during the control period (time, -30 to $0 \mathrm{~min}$ ). Tetanic stimulation was applied at time $0 . c$, Depolarization caused by high-frequency stimulation $(100 \mathrm{~Hz}$ for $1 \mathrm{sec})$ in the presence of $50 \mu \mathrm{M}$ D-APV and after washout of the antagonist. The stimulus strength was adjusted to evoke an EPSP that had an initial slope value of 0.16 to $0.18 \mathrm{mV} / \mathrm{msec}$, thus the depolarization in the presence of APV was similar between the wild-type and H-ras $(-/-)$ mice. The stimulus artifacts are truncated. $d$, Depolarization at $150 \mathrm{msec}$ from the beginning of tetanic stimulation was measured in the presence of $50 \mu \mathrm{M}$ D-APV and then $20 \mathrm{~min}$ after washout of the antagonist. NMDA receptor-dependent depolarization was calculated by subtracting the value in APV from that after washout, which included both NMDA and AMPA receptor-mediated depolarization. In the presence of APV, depolarization solely mediated by AMPA receptors was recorded. NMDA receptor-dependent depolarization was calculated by subtracting AMPA receptor-dependent depolarization from the total depolarization in the absence of APV. The ratio of NMDA to AMPA receptor-dependent depolarization was significantly larger $(p<0.04)$ in the H-ras $(-/-)$ than in wild-type mice.

the wild-type mice. To saturate LTP, high-frequency stimulation was repeatedly applied until there was no more potentiation (Fig. 5c). The saturation level of H-ras(-/-) slices (229.8 \pm $15.6 \%$ of control, $n=4$ slices and 4 mice) was not significantly different ( $p>0.3$ ) (Fig. $5 d$ ) from that of wild-type slices (222.3 \pm $21.1 \%, n=4$ slices and 4 mice), suggesting that the expression mechanisms are unchanged. Because many reports suggest that LTP is expressed, at least in part, by an increase in AMPA receptor sensitivity (Davies et al., 1989; Manabe et al., 1992; Manabe and Nicoll, 1994; Isaac et al., 1995; Liao et al., 1995), the larger magnitude of LTP could be explained by a downregulation of the AMPA receptor in naive slices from the H-ras $(-/-)$ mice, which could also account for the higher ratio of NMDA/AMPA synaptic responses (Fig. 3a,b). However, the results of the LTP saturation experiments, together with those of the experiments examining the input-output relationships of AMPA responses (Fig. $3 d$ ), rule out this possibility, because the saturation level of LTP in the H-ras $(-/-)$ mice should be higher than that in the wild-type mice if the basal level of AMPA sensitivity in H-ras $(-/-)$ mice is lower. It is thus unlikely that the enhanced LTP in H-ras (-/-) mice is attributable to a downregulation of the AMPA receptor sensitivity, thus further supporting the se- 

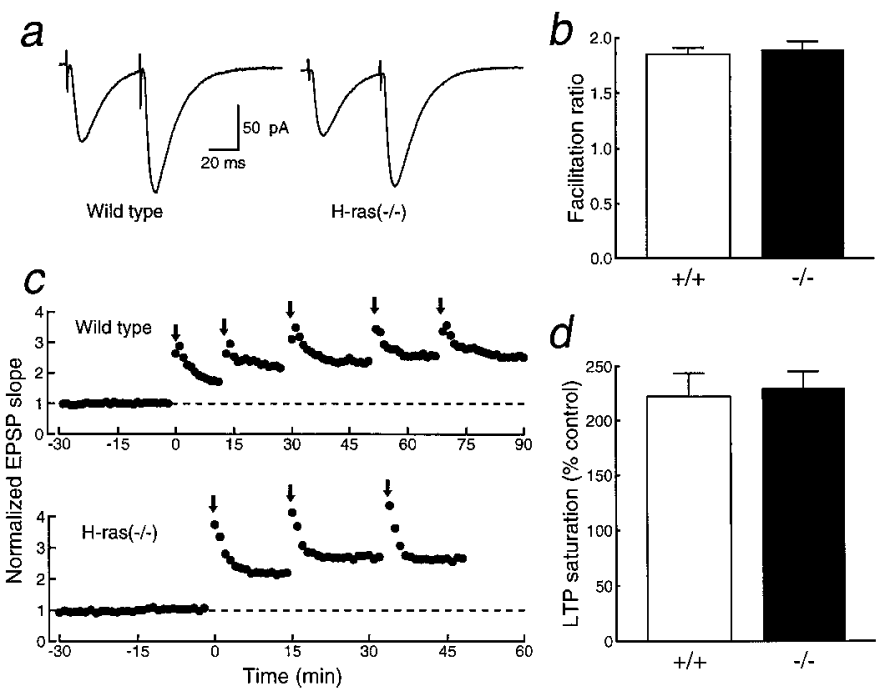

Figure 5. The LTP modulation is not mediated by a change in presynaptic release mechanisms but by a change in the postsynaptic induction mechanism. $a$, PPF of synaptic responses was induced by delivering afferent fiber stimulation twice at an interstimulus interval of $50 \mathrm{msec}$. Cells were voltage-clamped at $-90 \mathrm{mV} . b$, Averaged values of PPF. The facilitation ratios were calculated by dividing the amplitude of the second EPSCs by that of the first EPSCs. Ten consecutive traces were averaged, and the amplitude of the averaged trace was measured. There was no significant difference in PPF between the wild-type and H-ras $(-/-)$ mice. $c$, The saturation level of LTP in the H-ras $(-/-)$ mice is similar to that in the wild-type mice. Examples of LTP saturation in the wild-type and the H-ras $(-/-)$ mouse. Tetanic stimulation was repeatedly applied at the times indicated by the arrows. Each data point represents an averaged slope value of six consecutive EPSPs, normalized to the value during the control period. $d$, Summary of LTP saturation measurements. There was no significant difference between the two groups.

lective enhancement of the NMDA synaptic responses in H-ras(-/-) mice.

\section{DISCUSSION}

The NMDA receptor channel plays a central role in the development (McDonald and Johnston, 1990), plasticity (Malenka and Nicoll, 1993), and neurotoxicity (Choi, 1988) in the CNS. The essential role of NMDA receptors in synaptic plasticity, in particular in the CA1 region of the hippocampus, has been described by many researchers (Malenka and Nicoll, 1993). When NMDA receptor activation is blocked by an antagonist, LTP induced by standard procedures is inhibited (Collingridge et al., 1983). The knockout of one of the NMDA receptor subunits, NR2A, causes a reduction in the NMDA synaptic responses in the CA1 region, resulting in a decrease in the magnitude of LTP (Sakimura et al., 1995). Furthermore, a partial blockade of NMDA receptor activity results in no change or, in some cases, in long-term depression of synaptic transmission, depending on the degree of the blockade (Cummings et al., 1996). However, it is unknown as to whether LTP is enhanced when the NMDA responses are increased. In our present study, NMDA synaptic responses were selectively enhanced without apparent changes in the presynaptic release probability in H-ras $(-/-)$ mice, thus enabling us to examine the effect of a selective enhancement of NMDA receptor activity on LTP induction. Recently, two kinds of knock-out mice, the nociceptin receptor-deficient mice (Manabe et al., 1998) and the PSD-95-deficient mice (Migaud et al., 1998), have been reported to show an enhancement of LTP. Because both knock-out mice showed normal NMDA synaptic responses, the mechanism of the enhancement of LTP in our H-ras $(-/-)$ mice is different from those in the nociception receptor- and PSD-95-deficient mice. Furthermore, we confirm that the amount of PSD-95 in the NMDA receptor complex coimmunoprecipitated with an antiNR1 antibody is not significantly changed in H-ras $(-/-)$ mice, suggesting that the increase in LTP produced by loss of H-Ras does not involve a decrease in PSD-95 expression.

We found that the tyrosine phosphorylation of NR2A and NR2B subunits of NMDA receptors was increased in the H-ras (-/-) hippocampus. The NMDA synaptic responses were increased in baseline synaptic transmission, as well as during tetanic stimulation. The potentiated NMDA synaptic response is probably attributable to the increase in tyrosine phosphorylation of the postsynaptic receptors in the mutant mice, because the tyrosine phosphorylation of NMDA receptors is reported to enhance the activity of NMDA receptor (Wang and Salter, 1994; Yu et al., 1997). Thus, the regulation of synaptic plasticity via its regulation of the NMDA receptor phosphorylation in the adult CNS may be a novel H-Ras function. The signal transduction pathway from H-Ras proteins to NMDA receptors remains to be elucidated. It has been shown that PTKs, such as Src family kinases, exist upstream of Ras in signal transduction and positively regulate Ras activities (Sadoshima and Izumo, 1996). Our results suggest that the Ras protein inhibits the PTK activities on NMDA receptors by an unknown pathway.

We, however, could not exclude the possibility that upregulation of NMDA synaptic responses and enhancement of LTP in H-ras (-/-) mice might be caused indirectly by an impairment in neuronal development but not directly by the lack of H-Ras in adult hippocampal neurons, because H-Ras proteins have been shown to play a critical role in the proliferation and development in a variety of cell types and at different developmental stages. In that case, upregulation of tyrosine phosphorylation of NMDA receptors might be caused by the absence of H-Ras during development but not by the deficiency of H-Ras-mediated pathways acutely activated by the extracellular signals in the adult hippocampus. In addition, H-ras $(-/-)$ hippocampus might have morphological changes on the subcellular level, such as increase of dendritic spines expressing NMDA receptors but not AMPA receptors, although we could not find a significant morphological abnormality in H-ras $(-/-)$ brain, including the hippocampus. Furthermore, the larger depolarization and enhancement of LTP could be explained by the modification of voltage-dependent channels in the H-ras $(-/-)$ mice. However, we did not observe any difference between the wild-type and $\mathrm{H}-\operatorname{ras}(-/-)$ mice in the depolarization during the tetanus in the presence of APV (Fig. $4 c$ ), suggesting that the voltage-dependent component may not be modulated by the mutation. Even in the presence of APV, the depolarization during tetanus is very large, which should activate voltage-dependent channels considerably. Thus, it is rather unlikely that the modulation of voltage-dependent channels is the primary cause of the enhancement of LTP.

Ras proteins are activated by GEFs, which promote the exchange of bound GDP for GTP, and inactivated by GAPs, which stimulate the intrinsic Ras GTPase activity. Ras GEFs include Ras-GRF (CDC25 Mm) (Martegani et al., 1992; Shou et al., 1992) and Ras-GRF2 (Fam et al., 1997), mSOS1 and mSOS (Bowtell et al., 1992; Chardin et al., 1993), Ras-GRP (calcium- and diacylglycerol-regulated GEFII) (Ebinu et al., 1998; Kawasaki et al., 1998), and SmgGDS (Mizuno et al., 1991). Of these, mice lacking Ras-GRF showed normal LTP, although the analysis on 
properties of basal synaptic transmission revealed that RasGRF $(-/-)$ mice showed larger EPSPs in the CA1 region of the hippocampus (Brambilla et al., 1997). On the other hand, in our H-ras (-/-) mice, LTP is enhanced, but basal synaptic transmission mediated by AMPA receptors is not changed. Ras-GRF specifically activates H-Ras proteins among three mammalian Ras proteins in vivo (Jones and Jackson, 1998). Although the Ras activity was not measured in the Ras-GRF $(-/-)$ mice, it is possible that, in the Ras-GRF(-/-) mice, the H-Ras activity was not reduced because of the compensation of other Ras GEFs existing in the hippocampus. In that case, the electrophysiological phenotype in the Ras-GRF(-/-) mice could be attributable to downregulation of other target molecules of Ras-GRF. In the RasGAP family, recently cloned SynGAP exists in the PSD fraction and is included in the NMDA receptor complex (Chen et al., 1998; Kim et al., 1998), suggesting the involvement of Ras proteins in the NMDA receptor regulation.

Although Ras proteins have been implicated in cell proliferation and differentiation, and thus in the cellular functions that are critical for the development of the organism, our present study revealed a novel link between the H-Ras protein and the NMDA receptor via the Ras pathway. Because the NMDA receptor plays a central role in the modulation of synaptic transmission in the CNS and learning and memory, the regulation of activitydependent synaptic plasticity and learning and memory in adult animals may be another major and pivotal role for Ras proteins.

\section{REFERENCES}

Bliss TVP, Collingridge GL (1993) A synaptic model of memory: longterm potentiation in the hippocampus. Nature 361:31-39.

Bowtell D, Fu P, Simon M, Senior P (1992) Identification of murine homologues of the Drosophila son of sevenless gene: potential activators of ras. Proc Natl Acad Sci USA 89:6511-6515.

Brambilla R, Gnesutta N, Minichiello L, White G, Roylance AJ, Herron CE, Ramsey M, Wolfer DP, Cestari V, Rossi-Arnaud C, Grant SG, Chapman PF, Lipp HP, Sturani E, Klein R (1997) A role for the Ras signalling pathway in synaptic transmission and long-term memory. Nature 390:281-286.

Carlin RK, Grab DJ, Cohen RS, Siekevitz P (1980) Isolation and characterization of postsynaptic densities from various brain regions: enrichment of different types of postsynaptic densities. J Cell Biol 86:831-845.

Chardin P, Camonis JH, Gale NW, van Aelst L, Schlessinger J, Wigler MH, Bar-Sagi D (1993) Human Sos1-a guanine nucleotide exchange factor for Ras that binds to GRB2. Science 260:1338-1343.

Chen H-J, Rojas-Soto M, Oguni A, Kennedy MB (1998) A synaptic Ras-GTPase activating protein (p135 SynGAP) inhibited by CaM kinaseII. Neuron 20:895-904.

Chen L, Huang L-YM (1992) Protein kinase C reduces $\mathrm{Mg}^{2+}$ block of NMDA-receptor channels as a mechanism of modulation. Nature 356:521-523.

Choi DW (1988) Calcium-mediated neurotoxicity: relationship to specific channel types and role in ischemic damage. Trends Neurosci 11:465-469.

Collingridge GL, Kehl SJ, McLennan H (1983) Excitatory amino acids in synaptic transmission in the Schaffer collateral-commissural pathway of the rat hippocampus. J Physiol (Lond) 334:33-46.

Cummings JA, Mulkey RM, Nicoll RA, Malenka RC (1996) $\mathrm{Ca}^{2+}$ signaling requirements for long-term depression in the hippocampus. Neuron 16:825-833.

Davies SN, Lester RAJ, Reymann KG, Collingridge GL (1989) Temporally distinct pre- and post-synaptic mechanisms maintain long-term potentiation. Nature 338:500-503.

Ebinu JO, Bottorf DA, Chan EYW, Stang SL, Dunn RJ, Stone JC (1998) Ras GRP, a Ras guanyl nucleotide-releasing protein with calcium- and diacylglycerol-binding motifs. Science 280:1082-1088.

Ellis RW, Defeo D, Shih TY, Gonda MA, Young HA, Tsuchida N, Lowy DR, Scolnick EM (1981) The p21 src genes of Harvey and Kirsten sarcoma viruses originate from divergent members of a family of normal vertebrate genes. Nature 292:506-511.

English JD, Sweatt JD (1997) A requirement for the mitogen-activated protein kinase cascade in hippocampal long term potentiation. J Biol Chem 272:19103-19106.

Fam NP, Fan WT, Wang Z, Zhang LJ, Chen H, Moran MF (1997) Cloning and characterization of Ras-GRF2, a novel guanine nucleotide exchange factor for Ras. Mol Cell Biol 17:1396-1406.

Isaac JTR, Nicoll RA, Malenka RC (1995) Evidence for silent synapses: implications for the expression of LTP. Neuron 15:427-434.

Ishii T, Moriyoshi K, Sugihara H, Sakurada K, Kadotani H, Yokoi M, Akazawa C, Shigemoto R, Mizuno N, Masu M, Nakanishi S (1993) Molecular characterization of the family of the $N$-methyl-D-aspartate receptor subunits. J Biol Chem 268:2836-2843.

Jones MK, Jackson JH (1998) Ras-GRF activates Ha-Ras, but not N-Ras or K-Ras 4B, protein in vivo. J Biol Chem 273:1782-1787.

Kawasaki H, Springett GM, Toki S, Canales JJ, Harlan P, Blumenstiel JP, Chen EJ, Bany IA, Mochizuki N, Ashbacher A, Matsuda M, Housman DE, Graybiel AM (1998) A Rap guanine nucleotide exchange factor enriched highly in the basal ganglia. Proc Natl Acad Sci USA 95:13278-13283.

Kim JH, Liao D, Lau L-F, Huganir RL (1998) SynGAP: a Synaptic RasGAP that associates with the PSD-95/SAP90 protein family. Neuron 20:683-691.

Kutsuwada T, Kashiwabuchi N, Mori H, Sakimura K, Kushiya E, Araki K, Meguro H, Masaki H, Kumanishi T, Arakawa M, Mishina M (1992) Molecular diversity of the NMDA receptor channel. Nature 358:36-41.

Leon J, Guerrero I, Pellicer A (1987) Differential expression of the ras gene family in mice. Mol Cell Biol 7:1535-1540.

Liao D, Hessler NA, Malinow R (1995) Activation of postsynaptically silent synapses during pairing-induced LTP in CA1 region of hippocampal slice. Nature 375:400-404.

Lowy DR, Willumsen BM (1993) Function and regulation of ras. Annu Rev Biochem 62:851-891.

Lynch G, Larson J, Kelso S, Barrionuevo G, Schottler F (1983) Intracellular injections of EGTA block induction of hippocampal long-term potentiation. Nature 305:719-721.

Malenka RC, Nicoll RA (1993) NMDA-receptor-dependent synaptic plasticity: multiple forms and mechanisms. Trends Neurosci 16:521-527.

Malenka RC, Kauer JA, Zucker RS, Nicoll RA (1988) Postsynaptic calcium is sufficient for potentiation of hippocampal synaptic transmission. Science 242:81-84.

Manabe T, Nicoll RA (1994) Long-term potentiation: evidence against an increase in transmitter release probability in the CA1 region of the hippocampus. Science 265:1888-1892.

Manabe T, Renner P, Nicoll RA (1992) Postsynaptic contribution to long-term potentiation revealed by the analysis of miniature synaptic currents. Nature 355:50-55.

Manabe T, Wyllie DJA, Perkel DJ, Nicoll RA (1993) Modulation of synaptic transmission and long-term potentiation: effects on paired pulse facilitation and EPSC variance in the CA1 region of the hippocampus. J Neurophysiol 70:1451-1459.

Manabe T, Noda Y, Mamiya T, Katagiri H, Houtani T, Nishi M, Noda T, Takahashi T, Sugimoto T, Nabeshima T, Takeshima H (1998) Facilitation of long-term potentiation and memory in mice lacking nociceptin receptors. Nature 394:577-581.

Martegani E, Vanoni M, Zippel R, Coccetti P, Brambilla R, Ferrari C, Sturani E, Alberghina L (1992) Cloning by functional complementation of a mouse cDNA encoding a homologue of CDC25, a Saccharomyces cerevisiae RAS activator. EMBO J 11:2151-2157.

Mayer ML, Westbrook GL, Guthrie PB (1984) Voltage-dependent block by $\mathrm{Mg}^{2+}$ of NMDA responses in spinal cord neurones. Nature 309:261-263.

McDonald JW, Johnston MV (1990) Physiological and pathophysiological roles of excitatory amino acids during central nervous system development. Brain Res Rev 15:41-70.

Migaud M, Charlesworth P, Dempster M, Webster LC, Watabe AM, Makhinson M, He Y, Ramsay MF, Morris RG, Morrison JH, O’Dell TJ, Grant SG (1998) Enhanced long-term potentiation and impaired learning in mice with mutant postsynaptic density-95 protein. Nature 396:433-439.

Mizuno T, Kaibuchi K, Yamamoto T, Kawamura M, Sakoda T, Fujioka H, Matsuura Y, Takai Y (1991) A stimulatory GDP/GTP exchange protein for smg p21 is active on the post-translationally processed form of c-Ki-ras and rhoA p21. Proc Natl Acad Sci USA 88:6442-6446. 
Monyer H, Sprengel R, Schoepfer R, Herb A, Higuchi M, Lomeli H, Burnashev N, Sakmann B, Seeberg PH (1992) Heteromeric NMDA receptors: molecular and functional distinction of subtypes. Science 256:1217-1221.

Nicoll RA, Malenka RC (1995) Contrasting properties of two forms of long-term potentiation in the hippocampus. Nature 377:115-118.

Nowak L, Bregestovski P, Ascher P, Herbet A, Prochiantz A (1984) Magnesium gates glutamate-activated channels in mouse central neurones. Nature 307:462-465.

Rijksen G, van Oirschot BA, Staal GEJ (1991) Nonradioactive assays of protein-tyrosine kinase activity using anti-phosphotyrosine antibodies. Methods Enzymol 200:98-107.

Ruta M, Wolford R, Dhar R, DeFeo-Jones D, Ellis R, Scolnick EM (1986) Nucleotide sequence of the two rat cellular ras $\mathrm{H}$ genes. Mol Cell Biol 6:1706-1710.

Sadoshima J, Izumo S (1996) The heterotrimeric $\mathrm{G}_{\mathrm{q}}$ protein-coupled angiotensin II receptor activates $\mathrm{p} 21^{\text {ras }}$ via the tyrosine kinase-ShcGrb2-Sos pathway in cardiac myocytes. EMBO J 15:775-787.

Sakimura K, Kutsuwada T, Ito I, Manabe T, Takayama C, Kushiya E, Yagi T, Aizawa S, Inoue Y, Sugiyama H, Mishina M (1995) Reduced hippocampal LTP and spatial learning in mice lacking NMDA receptor $\epsilon 1$ subunit. Nature 373:151-155.

Sheng M, Cummings J, Roldan LA, Jan YN, Jan LY (1994) Changing subunit composition of heteromeric NMDA receptors during development of rat cortex. Nature 368:144-147.

Shimizu K, Goldfarb M, Suard Y, Perucho M, Li Y, Kamata T, Feramisco J, Stavnezer E, Fogh J, Wigler MH (1983) Three human transforming genes are related to the viral ras oncogenes. Proc Natl Acad Sci USA 80:2112-2116.

Shou C, Farnsworth CL, Neel BG, Feig LA (1992) Molecular cloning of cDNAs encoding a guanine-nucleotide-releasing factor for Ras p21. Nature 358:351-354.

Wang YT, Salter MW (1994) Regulation of NMDA receptors by tyrosine kinases and phosphatases. Nature 369:233-235.

Yu X-M, Askalan R, Keil IIGJ, Salter MW (1997) NMDA channel regulation by channel-associated protein tyrosine kinase Src. Science 275:674-678.

Zucker RS (1989) Short-term synaptic plasticity. Annu Rev Neurosci 121:13-31. 